\title{
Defining the inflammatory signature of human lung explant tissue in the presence and absence of glucocorticoid [version
}

\section{1; peer review: 2 approved]}

\author{
Tracy L Rimington (iD1, Emily Hodge 1, Charlotte K Billington1, Sangita Bhaker1, \\ Binaya K C (D1) 2, Iain Kilty ${ }^{3}$, Scott Jelinsky ${ }^{3}$, Ian P Hall1, Ian Sayers ${ }^{1}$ \\ ${ }^{1}$ Division of Respiratory Medicine, University of Nottingham, Nottingham, UK \\ ${ }^{2}$ Department of Mechanical Engineering, Kathmandu University, Dhulikhel, Nepal \\ ${ }^{3}$ Inflammation \& Remodelling Research Unit, Pfizer Inc, Cambridge, MA, USA
}

\author{
V1 First published: 11 Apr 2017, 6:460 \\ https://doi.org/10.12688/f1000research.10961.1 \\ Latest published: $11 \mathrm{Apr} 2017,6: 460$ \\ https://doi.org/10.12688/f1000research.10961.1
}

\section{Open Peer Review}

Approval Status

1 2

version 1

11 Apr 2017

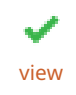

view

1. Yassine Amrani, University of Leicester, Leicester, UK

2. Colin D. Bingle (iD), University of Sheffield, Sheffield, UK

Any reports and responses or comments on the article can be found at the end of the article. 
inflammatory airway disease.

Abbreviations: COPD: Chronic Obstructive Pulmonary Disease; ICS:

inhaled corticosteroids; LPS: lipopolysaccharide; IL-1ß: interleukin-1

beta; PSF: penicillin, streptomycin and fungizone

\section{Keywords}

COPD, asthma, chemokines, inflammation, lung, multiplex, luminex, tissue explant, ex-vivo

Corresponding author: Tracy L Rimington (tracy.rimington@nottingham.ac.uk)

Competing interests: IK and SJ are employees of Pfizer Inc. Pfizer employees, IK and SJ were involved in study design, decision to publish and approved the final manuscript.

Grant information: The study was funded by Pfizer Inc.

Copyright: @ 2017 Rimington TL et al. This is an open access article distributed under the terms of the Creative Commons Attribution License, which permits unrestricted use, distribution, and reproduction in any medium, provided the original work is properly cited. Data associated with the article are available under the terms of the Creative Commons Zero "No rights reserved" data waiver (CC0 1.0 Public domain dedication).

How to cite this article: Rimington TL, Hodge E, Billington CK et al. Defining the inflammatory signature of human lung explant tissue in the presence and absence of glucocorticoid [version 1; peer review: 2 approved] F1000Research 2017, 6:460 https://doi.org/10.12688/f1000research.10961.1

First published: 11 Apr 2017, 6:460 https://doi.org/10.12688/f1000research.10961.1 


\section{Introduction}

Obstructive lung diseases such as asthma and Chronic Obstructive Pulmonary Disease (COPD) are characterised by inflammation which can affect both large and small airways ${ }^{1}$. Treatment options for these inflammatory lung diseases remain limited and not all patients respond to the most commonly used medicines, including inhaled corticosteroids (ICS) and $\beta$-2 adrenergic receptor agonists ${ }^{2-5}$. There is a need for new treatments for both asthma and COPD, and particularly for approaches which target inflammation ${ }^{4}$, especially in the small airways, which have been increasingly recognised as an important site of inflammation ${ }^{6,7}$.

Whilst there have been some studies which have used ex vivo cell or tissue to look at inflammatory responses, the lack of a robust human tissue system has to some extent hindered pre-clinical drug development and mechanistic studies in these diseases. Animal models have long been used to try and predict efficacy in human disease but findings in animal models often fail to predict responses in humans. This is particularly true for diseases such as asthma and COPD for which animal models are only able to recapitulate some of the features of the human disease ${ }^{2,8,9}$. A human tissue explant model would therefore complement those in vivo mouse models which currently exist.

Preliminary data exist demonstrating that ex vivo human lung tissue models can be used to study the effect of allergens and other inflammatory stimuli on selected cytokine responses ${ }^{10,11}$. Our aim was to develop a reproducible human lung tissue explant model which could be used for target validation and to help investigate mechanisms underlying inflammation relevant to airway disease.

In this study we assessed human lung tissue explants ex vivo to define inflammatory signalling using multiplex cytokine assays. In order to elicit an inflammatory response in human lung tissue bacterial lipopolysaccharide (LPS) and interleukin-1 beta (IL-1 $\beta$ ) were used ${ }^{12-14}$. We defined the cytokine and chemokine signature of this tissue in response to these stimuli and also provide data on the reproducibility of this model by assessing responses to 21 chemokines, growth factors and cytokines. To determine the usefulness of the model to identify anti-inflammatory mechanisms we also examined the effect of potential inhibitory responses using dexamethasone.

\section{Methods}

Human parenchymal lung tissue was obtained from the Nottingham Research Biorepository from patients undergoing lung resection surgery at Nottingham University Hospitals, UK. Written consent was obtained from all patients and the study was approved by North West 7 REC - Greater Manchester Central (ethics reference 10/H1008/72). The patient demographics of the six donor subjects used in the current study are shown in Supplementary table 1. The mean age of donors was $75.5 \pm 10.5$ years ( 4 females and 2 males). In total, three individuals were ex-smokers (stopped $\geq 3$ years), two were recent smokers (stopped $\leq 3$ years) and one was never a smoker. Three subjects had spirometry suggesting the presence of COPD.
Lung tissue was dissected into $30-100 \mathrm{mg}$ (wet weight) pieces and incubated for 24h in RPMI 1640 (with $2.05 \mathrm{mM}$ L-glutamine and $25 \mathrm{mM}$ HEPES) (Sigma, 51536C) containing Antibiotic Antimycotic Solution (PSF, penicillin, streptomycin and fungizone) (Sigma, A5955). Following initial incubation, media was replaced, and following the addition of LPS or IL-1 $\beta(1 \mu \mathrm{g} / \mathrm{ml}$ or $10 \mathrm{ng} / \mathrm{ml}$ respectively) or vehicle controls in the presence or absence of $1 \mu \mathrm{M}$ dexamethasone, the tissue was incubated for a further $24 \mathrm{~h}$, followed by the collection of supernatants. All experimental conditions were prepared in duplicate.

We designed a custom multiplex panel of 21 Luminex assays to provide comprehensive information on the protein secretory profile of the human lung tissue. This panel was designed to encompass the main inflammatory pathways activated in the lung, including chemokine, cytokine and growth factor pathways (Supplementary table 2).

Luminex assays (supplied by R\&D, product code LXSAHM) were performed according to the manufacturer's recommendations using a custom Magnetic Luminex Screening Assay with a Human Premixed Multi-Analyte Kit (R\&D systems). Each duplicate supernatant from the lung tissue explant experiment was assayed in duplicate.

Results were normalised using wet tissue weights in individual experiments and data were normalised to maximal inflammatory stimulus level (i.e. LPS or IL-1 $\beta, 100 \%$ ) in each experiment prior to combining data. Statistical analysis was performed using ANOVA and post-hoc Dunnett's multiple comparisons test. Statistical analysis was performed using GraphPad Prism software (Version 6, GraphPad Software Inc.).

\section{Ethics approval and consent statement}

Written consent was obtained from all patients and the study was approved under ethics reference 10/H1008/72, 12/SC/0526 and $08 / \mathrm{H} 0304 / 56+5$. All samples were obtained and research conducted under the approval of the Nottingham Health Science Biobank, Arden Tissue Bank and Papworth Hospital Research Tissue Bank. Written consent was obtained from all patients to publish research findings obtained from the use of patient samples under the approval of the Research Tissue Banks.

\section{Results}

Using the multiplex approach, 12 of the 21 inflammatory analytes assayed generated quantifiable signals in the Luminex assay across all donors following $24 \mathrm{~h}$ incubation under baseline (unstimulated) conditions (Figure 1 and Supplementary table 3). The analytes detected were a range of chemokines including CCL3, CCL4, cytokines including IL-6, CXCL8 and several growth factors including VEGF (Figure 1 and Supplementary table 3).

With the exception of IL-2, there was a significant induction of levels of all analytes detectable following LPS stimulation (Figure 1A and 1B). The fold stimulation within donor samples was reasonably reproducible for CXCL8 (3.5-fold), CCL3 ( 33-fold), CCL4 ( 18-fold), CCL22 (1.6-fold), GM-CSF 

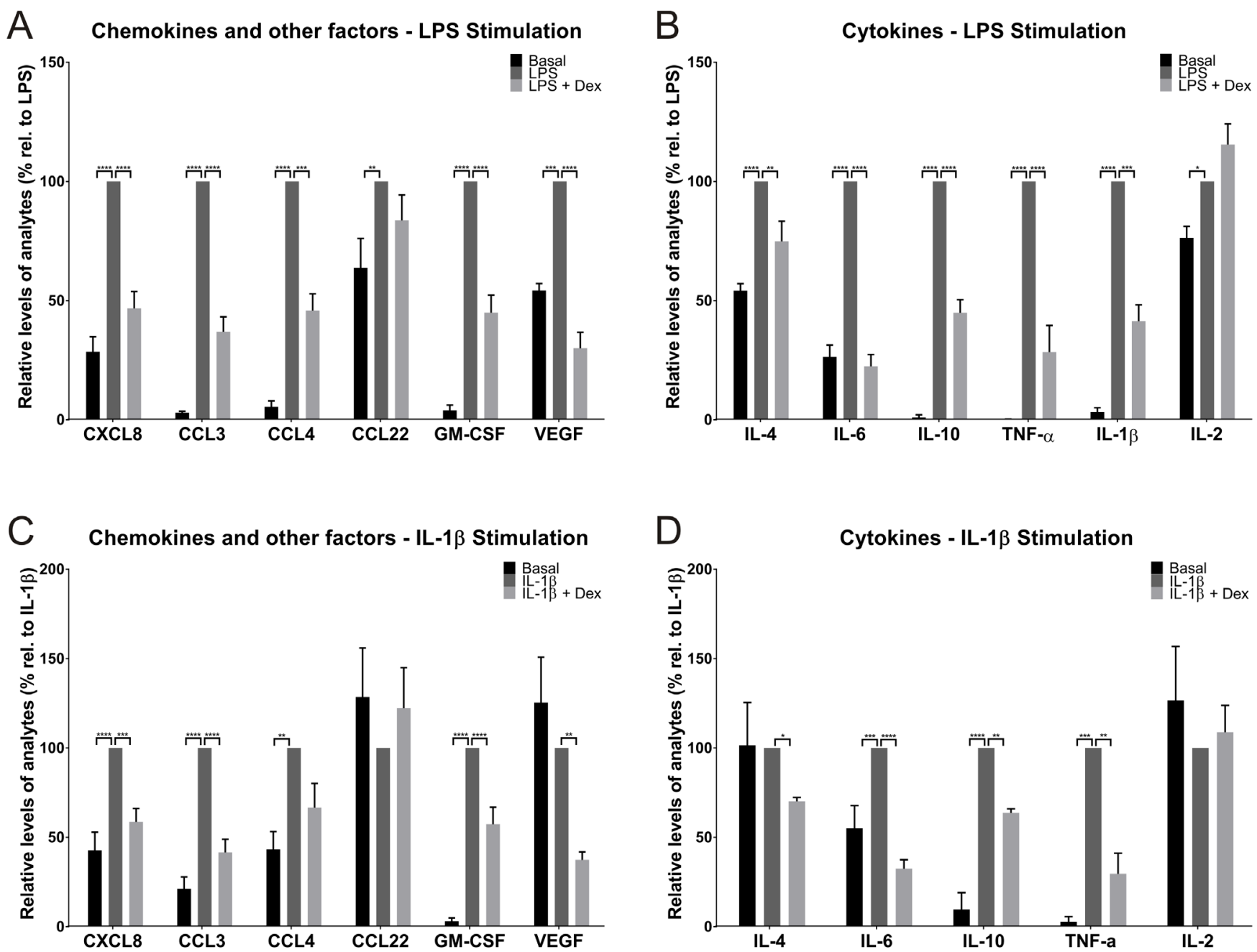

Figure 1. The secretory profile of ex vivo human lung tissue following LPS and IL-1 $\beta$ stimulation. LPS significantly induced the release of 12 analytes in cultured lung tissue explants, including chemokines and other factors (e.g. growth factors) (A) and cytokines (B). For 10 of these analytes, this response was attenuated with dexamethasone treatment. Results were normalised using tissue mass and data were then normalised to the LPS stimulation (100\%) from each donor and are presented as mean $( \pm$ SEM, $n=6)$. IL-1 $\beta$ significantly induced the release of 7 analytes in cultured lung tissue explants, including chemokines and other factors (C) and cytokines (D). For 6 of these analytes, this response was attenuated with dexamethasone treatment. Results were normalised using wet tissue mass and data were then normalised to the IL-1 $\beta$ stimulation (100\%) from each donor and are presented as mean ( \pm SEM, $n=4)$. Due to limited tissue availability for two donors, it was not possible to obtain tissue from all six donors for the IL-1 $\beta$ experiments.

( 25-fold) and VEGF (1.8-fold) (Figure 1A). There was also a significant cytokine induction in the tissue, characterised by elevated levels of IL-4 (1.8-fold), IL-6 (3.8-fold), IL-10 ( 96-fold), TNF- $\alpha$ ( 600-fold), IL-1 $\beta$ ( 30-fold) and IL-2 (1.3) (Figure 1B). The absolute values (as opposed to the fold stimulations) varied to some extent across donors even when corrected for tissue wet weight.

From the 12 analytes that exhibited a significant LPS driven response, pre-treatment with dexamethasone $(1 \mu \mathrm{M})$ attenuated this response by $>50 \%$ for 9 of the analytes. Dexamethasone was unable to significantly attenuate the stimulation of CCL22 or IL-2 production, suggesting this induction was steroid insensitive (Figure 1A and 1B).
IL-1 $\beta$ was also able to induce an inflammatory response in the human lung tissue, however both the magnitude and diversity of the responses observed across the 21 analytes was diminished in comparison to LPS. IL-1 $\beta$ stimulated production of 7 of the analytes, and this response was attenuated by dexamethasone treatment for 6 of these targets (Figure 1C and 1D). The greatest level of induction was observed for TNF- $\alpha$ ( 35-fold), followed by GM-CSF ( 32-fold), IL-10 ( 10-fold), CCL3 ( 5-fold), CCL4 (2.3-fold), CXCL8 (2.3-fold) and IL-6 (1.8-fold) (Figure 1C and 1D). Treatment with dexamethasone attenuated these inflammatory responses to varying degrees, with the greatest reduction being TNF- $\alpha(\sim 70 \%)$, although the actual concentration of this analyte was low $(\sim 0.8 \mathrm{pg} / \mathrm{ml} / \mathrm{mg}$ tissue) compared to the LPS stimulated sample ( $\sim 30 \mathrm{pg} / \mathrm{ml} / \mathrm{mg}$ tissue) (Supplementary table 3$)$. 
Attenuation of the inflammatory response was $>35 \%$ for the remaining 5 analytes, for which statistically significant reductions were seen for IL-6, CCL3, GM-CSF, CXCL8 and IL-10. Although there was a $33 \%$ reduction in CCL4 following treatment with dexamethasone, this was not statistically significant (Figure 1C and 1D).

LPS induced a more pronounced inflammatory response than IL-1 $\beta$ when comparing absolute concentrations of the analytes measured (Supplementary table 3). Figure 2 allows direct comparisons to be made between the two pro-inflammatory stimuli, and provides insight into the degree of inter-donor variability observed in the model. Some donor variation was apparent for both CXCL8 and CCL3 at both basal levels and following stimulation (Figure 2A-D).

In order to further explore the degree of variability in responses, we measured CXCL8 production in tissue obtained from 5 additional subjects. The mean basal levels of CXCL8 produced (total of $\mathrm{n}=11$ donors) were 1941 (range 232-7927) $\mathrm{pg} / \mathrm{ml} / \mathrm{mg}$ tissue and the fold stimulation observed with LPS was 3.9-fold (range 2.2-12.7)

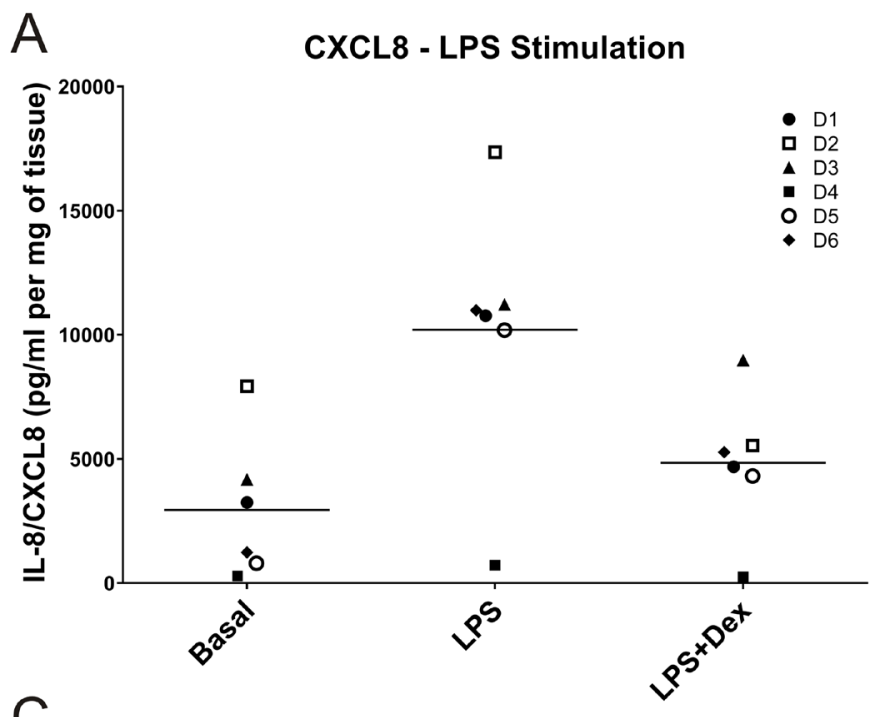

B
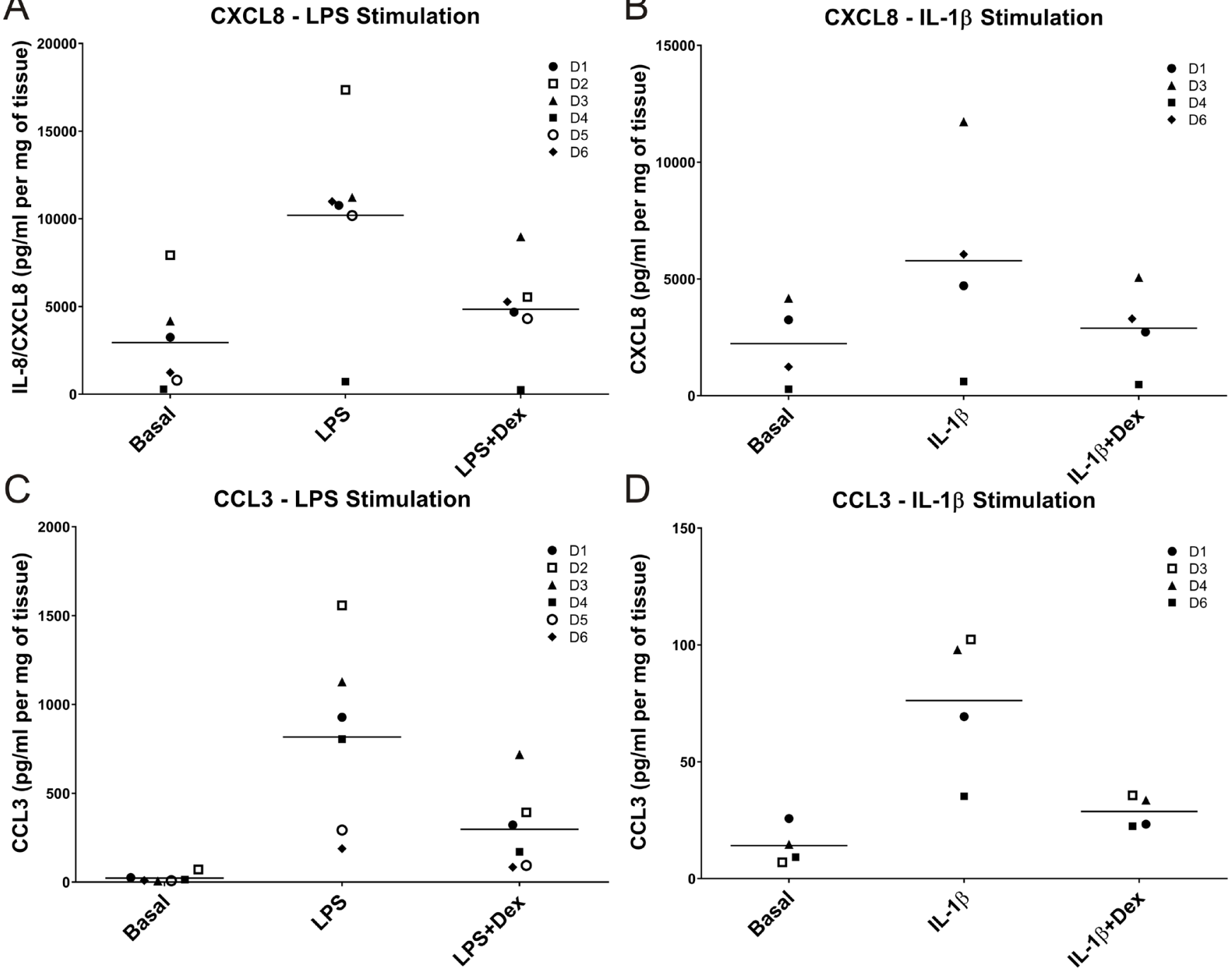

Figure 2. Comparison of concentration of CXCL8 and CCL3 following LPS and IL-1 $\beta$ stimulation and dexamethasone treatment. LPS and IL-1 $\beta$ both induced an inflammatory response in ex-vivo lung tissue, although the response with LPS was greater than with IL-1 $\beta$. Compared to the IL-1 $\beta$ stimulation, there was an overall 1.8-fold increase in CXCL8 concentration (A and B) following LPS stimulation and an overall 11-fold increase in levels of CCL3 (C and D). 
Dataset 1. LPS raw data

http://dx.doi.org/10.5256/f1000research.10961.d157792

Luminex raw data for LPS stimulated tissue (Donors $n=6$ )

Dataset 2. IL-1b raw data

http://dx.doi.org/10.5256/f1000research.10961.d157794

Luminex raw data for $\mathrm{IL}-1 \mathrm{~b}$ stimulated tissue (Donors $\mathrm{n}=4$ ).

\section{Discussion}

There is a need for well-characterised human lung tissue models to assess pro and anti-inflammatory responses in the lung and to help with target validation during the drug development process. We have therefore developed an explant model using ex-vivo human lung tissue to investigate the inflammatory responses induced using two physiologically relevant stimuli. We characterised responses using Luminex assays to simultaneously permit analysis of a range of cytokines and other mediators. We chose LPS as a stimulus to mimic bacterial infection and IL-1 $\beta$ as a more selective proinflammatory signal. The data presented demonstrate that reasonably reproducible responses can be obtained in this model despite there being an inevitable element of heterogeneity in the tissue obtained from each donor. We also used pre-treatment with dexamethasone as proof of concept to identify anti-inflammatory effects in this model. The reduction in inflammatory mediator responses observed after dexamethasone pre-treatment support the use of this model for investigation of potentially anti-inflammatory effects of novel compounds in the human lung.

Models currently used in airway disease research have limitations. For instance, rodent in vivo models have been heavily relied upon and whilst these can provide useful mechanistic insights they do not always translate well when assessing efficacy in human disease ${ }^{8,9}$. Human tissue based models should enhance mechanistic and pre-clinical studies and will hopefully prove more predictive for target validation for diseases such as asthma and COPD.

We describe here the inflammatory secretory profiles obtained using pro-inflammatory stimuli LPS and IL-1 $\beta$ in this model. Both induced release of a range chemokines, cytokines and growth factors. As would be expected, the magnitude of effect was greater with LPS than with IL-1 $\beta$. Appropriate vehicle controls were included in all experiments and did not produce responses. Some variability in both basal and stimulated levels of mediators was seen between donors, although within donor reproducibility of responses was generally good (Figure 2).

Bacterial infection and exacerbation are common in COPD and asthma patients ${ }^{12,13,15-17}$. The broad secretory profile that is obtained following LPS stimulation supports its role as a broad activator of intra-cellular signalling pathways. The responses we observed in the ex vivo model broadly mirror observations in the clinical setting; for example, IL-6, CXCL8 and TNF- $\alpha$ are elevated following COPD exacerbation in induced sputum or bronchoalveolar lavage samples ${ }^{15-17}$. The data presented here also agree with previous work assessing cytokine responses in a less extensively characterised human lung tissue model, in which TNF- $\alpha$, IL-1 $\beta$, IL-6, CXCL8 and IL-10 production was observed following LPS exposure or following influenza virus induced inflammation ${ }^{18,19}$.

IL-1 $\beta$ stimulation resulted in an induction of mediators where only 7 of the analytes measured increased by significant levels, and the magnitude of effect was lower than that seen with LPS stimulation, reflecting the more selective induction of signalling pathways with this agonist.

There is a pressing need for the development of new human disease models, in particular those which help reduce the need for animal models ${ }^{2,8,20}$. There are intensive efforts to reconstitute the key components of the airway to generate clinically relevant in vitro models to be used in basic research and compound evaluation, including lung-on-a chip ${ }^{21}$, dendritic cell-epitheliumfibroblast scaffolds ${ }^{22}$ and differentiated epithelial cell layers ${ }^{23}$. These approaches have both strengths and weaknesses; applicability to scale up is a strength but none are fully representative of an in vivo human lung. One of the advantages of the lung explant model over models such as air liquid interface culture of epithelial cells is maintenance of in vivo cell architecture without the need to induce differentiation in culture. Another approach that is growing in popularity and shares many of the advantages of an ex vivo tissue model is precision cut lung slices which provide a scaled model of the explant approach ${ }^{24,25}$. However, preparing precision cut lung slices from human tissue is technically much more difficult than from mouse tissue, and for the study of inflammatory approaches (as opposed to contractile responses) it offers no real advantages.

It is also possible that the use of a human tissue based approach could reduce the use of animals in target validation and overcome some of the obstacles and pitfalls faced when progressing from pre-clinical studies with animals to human trials ${ }^{2}$. However, it is also important to note that there are limitations; including limited accessibility to human tissue, the relatively heterogeneous nature of resection samples, and natural donor variation in responses.

\section{Conclusions}

In summary, we have demonstrated proof of concept that an ex vivo human lung tissue explant model can be used to mimic airway inflammation and provide low/medium throughput screening of anti-inflammatory properties of candidate drugs for the treatment of airway disease. This model should also help with target validation and reduce the reliance on animal models, thus reducing animal usage in the drug development process.

\section{Data availability}

Dataset 1: LPS raw data. Luminex raw data for LPS stimulated tissue (Donors $\mathrm{n}=6$ ).

\section{DOI, 10.5256/f1000research.10961.d157792 26}

Dataset 2: IL-1b raw data. Luminex raw data for IL-1b stimulated tissue (Donors $n=4$ ).

DOI, 10.5256/f1000research.10961.d15779427 
Author contributions

IS, IPH, IK and SJ designed the study. TLR assisted with study design, performed experiments and completed data analyses. $\mathrm{EH}$ assisted with study design and performed experiments. CKB assisted with study design and experiments. SB and BKC assisted with experiments. TLR, IS and IPH drafted the manuscript. All authors approved the final manuscript.
Competing interests

IK and SJ are employees of Pfizer Inc. Pfizer employees, IK and SJ were involved in study design, decision to publish and approved the final manuscript.

Grant information

The study was funded by Pfizer Inc.

\section{Supplementary material}

Supplementary Table 1: Patient demographics.

Click here to access the data.

Supplementary Table 2: Custom Luminex panel design and standard curve range of analytes measured.

Click here to access the data.

Supplementary Table 3: Concentration of analytes determined by Luminex.

Click here to access the data.

1. Brusselle G, Bracke $\mathrm{K}$ : Targeting immune pathways for therapy in asthma and chronic obstructive pulmonary disease. Ann Am Thorac Soc. 2014; 11(Suppl 5): S322-328

PubMed Abstract | Publisher Full Text

2. Edwards J, Belvisi M, Dahlen SE, et al:: Human tissue models for a human disease: what are the barriers? Thorax. 2015; 70(7): 695-697. PubMed Abstract | Publisher Full Text | Free Full Text

3. Hall IP, Sayers I: Pharmacogenetics and asthma: false hope or new dawn? Eur Respir J. 2007; 29(6): 1239-1245.

PubMed Abstract | Publisher Full Text

4. Portelli M, Sayers I: Genetic basis for personalized medicine in asthma. Expert Rev Respir Med. 2012; 6(2): 223-236. PubMed Abstract | Publisher Full Text

5. Sayers I, Hall IP: Pharmacogenetic approaches in the treatment of asthma. Curr Allergy Asthma Rep. 2005; 5(2): 101-108. PubMled Abstract | Publisher Full Text

6. Gentile DA, Skoner DP: New asthma drugs: small molecule inhaled corticosteroids. Curr Opin Pharmacol. 2010; 10(3): 260-265. PubMed Abstract | Publisher Full Text

7. Lahzami S, King GG: Targeting small airways in asthma: the new challenge of inhaled corticosteroid treatment. Eur Respir J. 2008; 31(6): 1145-1147. PubMed Abstract | Publisher Full Text

8. Holmes AM, Solari R, Holgate ST: Animal models of asthma: value, limitations and opportunities for alternative approaches. Drug Discov Today. 2011; 16(15-16): 659-670.

PubMed Abstract | Publisher Full Text

9. Wenzel S, Holgate ST: The mouse trap: It still yields few answers in asthma. Am J Respir Crit Care Med. 2006; 174(11): 1173-1176; discussion 1176-1178. PubMed Abstract | Publisher Full Text

10. Hackett TL, Scarci M, Zheng L, et al.: Oxidative modification of albumin in the parenchymal lung tissue of current smokers with chronic obstructive pulmonary disease. Respir Res. 2010; 11: 180 . PubMed Abstract | Publisher Full Text | Free Full Text

11. Chang $\mathrm{Y}, \mathrm{Al}$-Alwan $\mathrm{L}$, Alshakfa $\mathrm{S}$, et al.: Upregulation of IL-17A/F from human lung tissue explants with cigarette smoke exposure: implications for COPD. Respir Res. 2014; 15: 145

PubMed Abstract | Publisher Full Text | Free Full Text

12. Murakami D, Yamada H, Yajima T, et al.: Lipopolysaccharide inhalation exacerbates allergic airway inflammation by activating mast cells and promoting Th2 responses. Clin Exp Allergy. 2007; 37(3): 339-347. PubMed Abstract | Publisher Full Text

13. Lowe AP, Thomas RS, Nials AT, et al:: LPS exacerbates functional and inflammatory responses to ovalbumin and decreases sensitivity to inhaled fluticasone propionate in a guinea pig model of asthma. Br J Pharmacol. 2015 172(10): 2588-2603.

PubMed Abstract | Publisher Full Text | Free Full Text

14. Zhang H, Kim YK, Govindarajan A, et al.: Effect of adrenoreceptors on endotoxin-induced cytokines and lipid peroxidation in lung explants. $A m J$ Respir Crit Care Med. 1999; 160(5 Pt 1): 1703-1710.

PubMed Abstract | Publisher Full Text

15. Hacievliyagil SS, Gunen H, Mutlu LC, et al:: Association between cytokines in induced sputum and severity of chronic obstructive pulmonary disease. Respir Med. 2006; 100(5): 846-854.

PubMed Abstract | Publisher Full Text

16. Patel IS, Seemungal TA, Wilks M, et al:: Relationship between bacterial colonisation and the frequency, character, and severity of COPD exacerbations. Thorax. 2002; 57(9): 759-764.

PubMed Abstract | Publisher Full Text | Free Full Text

17. Tumkaya M, Atis S, Ozge C, et al:: Relationship between airway colonization, inflammation and exacerbation frequency in COPD. Respir Med. 2007; 101(4): 729-737.

PubMed Abstract | Publisher Full Text

18. Nicholas B, Staples KJ, Moese S, et al:: A novel lung explant model for the ex vivo study of efficacy and mechanisms of anti-influenza drugs. J Immunol. 2015; 194(12): 6144-6154. PubMed Abstract | Publisher Full Text | Free Full Text

19. Hackett TL, Holloway R, Holgate ST, et al.: Dynamics of pro-inflammatory and anti-inflammatory cytokine release during acute inflammation in chronic obstructive pulmonary disease: an ex vivo study. Respir Res. 2008; 9: 47. PubMed Abstract | Publisher Full Text | Free Full Text

20. Holgate S, Agusti A, Strieter RM, et al.: Drug development for airway diseases: looking forward. Nat Rev Drug Discov. 2015; 14(6): 367-368. PubMed Abstract | Publisher Full Text

21. Huh D, Matthews $\mathrm{BD}$, Mammoto A, et al:: Reconstituting organ-level lung functions on a chip. Science. 2010; 328(5986): 1662-1668. PubMed Abstract | Publisher Full Text

22. Harrington $\mathrm{H}, \mathrm{Cato} \mathrm{P}$, Salazar $\mathrm{F}$, et al.: Immunocompetent 3D model of human upper airway for disease modeling and in vitro drug evaluation. Mol Pharm. 
2014; 11(7): 2082-2091.

PubMed Abstract | Publisher Full Text | Free Full Text

23. Stewart CE, Torr EE, Mohd Jamili NH, et al: Evaluation of differentiated human bronchial epithelial cell culture systems for asthma research. J Allergy (Cairo). 2012; 2012: 943982.

PubMed Abstract | Publisher Full Text | Free Full Text

24. Neuhaus V, Schwarz K, Klee A, et al.: Functional testing of an inhalable nanoparticle based influenza vaccine using a human precision cut lung slice technique. PLoS One. 2013; 8(8): e71728.

PubMed Abstract | Publisher Full Text | Free Full Text

25. Lauenstein L, Switalla S, Prenzler F, et al.: Assessment of immunotoxicity induced by chemicals in human precision-cut lung slices (PCLS). Toxicol In Vitro. 2014; 28(4): 588-599.

PubMed Abstract | Publisher Full Text

26. Rimington $\mathrm{T}$, Hodge E, Billington $\mathrm{C}$, et al.: Dataset 1 in: Defining the inflammatory signature of human lung explant tissue in the presence and absence of glucocorticoid. F1000Research. 2017.

Data Source

27. Rimington $\mathrm{T}$, Hodge E, Billington $\mathrm{C}$, et al:: Dataset $\mathbf{2}$ in: Defining the inflammatory signature of human lung explant tissue in the presence and absence of glucocorticoid. F1000Research. 2017.

Data Source 


\section{Open Peer Review}

\section{Current Peer Review Status:}

\section{Version 1}

Reviewer Report 27 June 2017

https://doi.org/10.5256/f1000research.11814.r21789

(C) 2017 Bingle C. This is an open access peer review report distributed under the terms of the Creative Commons Attribution License, which permits unrestricted use, distribution, and reproduction in any medium, provided the original work is properly cited.

\section{Colin D. Bingle}

Academic Unit of Respiratory Medicine, Department of Infection, Immunity \& Cardiovascular Disease, University of Sheffield, Sheffield, UK

Tracy Rimington and colleagues present a novel preliminary analysis of the inflammatory signature of human lung explant tissue. They correctly identify that limitations in human lung tissue models has hindered pre-clinical and mechanistic studies and provide data to suggest that a simple explanted lung tissue model may have some utility in this area.

A significant advantage of this model is the lack of requirement for complex model development and should allow the technique to be utilised in any tissue culture facility with ease. The model takes multiple small pieces of human lung tissue and cultures them in a standard growth media for periods of up to 24 hours. Media is removed and then can be used for downstream assays. In this case media was used in a custom Luminex assay to detect a range of inflammatory mediators.

The results suggest that the model allows for the detection if secretion of $12 / 21$ analytes chosen and shows that secretion of these was modified by inclusion of the pro-inflammatory mediators, bacterial LPS and interleukin beta into the media.

This preliminary data suggests that this type of model could be further developed and may become a valuable tool for pulmonary research.

The current data shows how there is a high level of variability between different explants, both in terms of basal and stimulated levels. The reasons for this will need to be explored. Does it represent true variability between different donors or could it be due to the way in which individual donor explants are generated? Maybe the size of each tissue fragment will have a significant influence on responses?

It will also be helpful to explore the tissue viability and to investigate extending the time frame of the explant cultures? Again perhaps tissue fragment size will be an important variable. 
Overall, the data provide a useful primer to the further development of lung tissue explants as a research tool.

Is the work clearly and accurately presented and does it cite the current literature? Yes

Is the study design appropriate and is the work technically sound?

Yes

Are sufficient details of methods and analysis provided to allow replication by others? Yes

If applicable, is the statistical analysis and its interpretation appropriate? Yes

Are all the source data underlying the results available to ensure full reproducibility? Yes

Are the conclusions drawn adequately supported by the results? Yes

Competing Interests: No competing interests were disclosed.

Reviewer Expertise: My research focus is on pulmonary cell and molecular biology.

I confirm that I have read this submission and believe that I have an appropriate level of expertise to confirm that it is of an acceptable scientific standard.

Reviewer Report 26 April 2017

https://doi.org/10.5256/f1000research.11814.r21786

(C) 2017 Amrani Y. This is an open access peer review report distributed under the terms of the Creative Commons Attribution License, which permits unrestricted use, distribution, and reproduction in any medium, provided the original work is properly cited.

\section{Yassine Amrani}

Department of Infection, Immunity and Inflammation, University of Leicester, Leicester, UK

This interesting report describes the use of human lung tissue explants as an in vitro model to study responses to various proinflammatory stimuli. The authors showed that the model can be cultured for $24 \mathrm{hr}$ and retains responsiveness to LPS and IL-1 $\beta$ with the production of different cytokines and growth factors. Interestingly, the proinflammatory potential of cultured human lung tissue explants can still be modulated by dexamethasone, suggesting that the model would be ideal to test novel anti-inflammatory drugs. Overall the manuscript is clearly written and data are novel. There are some minor points that need clarifications. 
1. It would important to state how tissue viability was assessed following the 2 days culture

2. Please also provide, if possible, some representative picture of the histology of human lung tissue explants before and following the 2 day culture

3. It would better to express the data in Figure 1 as net cytokine increase rather than $\%$ of LPS.

Is the work clearly and accurately presented and does it cite the current literature?

Yes

Is the study design appropriate and is the work technically sound?

Yes

Are sufficient details of methods and analysis provided to allow replication by others?

Yes

If applicable, is the statistical analysis and its interpretation appropriate?

Yes

Are all the source data underlying the results available to ensure full reproducibility? Yes

Are the conclusions drawn adequately supported by the results?

Yes

Competing Interests: No competing interests were disclosed.

I confirm that I have read this submission and believe that I have an appropriate level of expertise to confirm that it is of an acceptable scientific standard. 
The benefits of publishing with F1000Research:

- Your article is published within days, with no editorial bias

- You can publish traditional articles, null/negative results, case reports, data notes and more

- The peer review process is transparent and collaborative

- Your article is indexed in PubMed after passing peer review

- Dedicated customer support at every stage

For pre-submission enquiries, contact research@f1000.com 